\title{
Incidence of cervical disease associated to HPV in human immunodeficiency infected women under highly active antiretroviral therapy
}

\author{
Martin Luther Koanga Mogtomo*1, Louise Carole Gouabe Malieugoue1, \\ Carolle Djiepgang 1 , Michel Wankam², Andre Moune ${ }^{3}$ and \\ Annie Ngono Ngane ${ }^{1}$
}

Address: ${ }^{1}$ Laboratory of Viral Oncology, Department of Biochemistry, Faculty of Sciences, University of Douala, Cameroon, ${ }^{2}$ Aids Care Unit and Gynaecology, Bonassama Hospital Douala, Cameroon and ${ }^{3}$ Pathology Unit, Douala General Hospital, Cameroon

Email: Martin Luther Koanga Mogtomo* - koanga@yahoo.com; Louise Carole Gouabe Malieugoue - mgouabe@yahoo.fr; Carolle Djiepgang - caroledjiepgang@yahoo.fr; Michel Wankam - mwankam@yahoo.fr; Andre Moune - amoune@yahoo.com; Annie Ngono Ngane - angono@yahoo.com

* Corresponding author

Published: 3 June 2009

Infectious Agents and Cancer 2009, 4:9 doi:10.1186/1750-9378-4-9

This article is available from: http://www.infectagentscancer.com/content/4/I/9

(C) 2009 Mogtomo et al; licensee BioMed Central Ltd.

This is an Open Access article distributed under the terms of the Creative Commons Attribution License (http://creativecommons.org/licenses/by/2.0), which permits unrestricted use, distribution, and reproduction in any medium, provided the original work is properly cited.
Received: 5 February 2009

Accepted: 3 June 2009

\begin{abstract}
Background: Women infected with human immunodeficiency virus (HIV) may be at higher risk of developing cervical cancer than non infected women. In a pilot study, we assessed the relationships among cervical cytology abnormalities associated to Human Papillomavirus (HPV), HIV infection and Highly Active Antiretroviral Therapy (HAART) on the development of Squamous Intraepithelial lesions (SILs). Out of the 70 HIV infected women from Douala -Cameroon (Central Africa) that we included in the study, half (35) were under HAART. After obtaining information related to their lifestyle and sexual behaviour, cervicovaginal samples for Pap smears and venous blood for CD4 count were collected and further divided into two groups based upon the presence or absence of cervical cytology abnormalities i.e. those with normal cervical cytology and those with low and high Squamous Intraepithelial lesions (LSIL, HSIL).
\end{abstract}

Results: Assessment was done according to current antiretroviral regimens available nationwide and CD4 count. It was revealed that $44.3 \%$ of HIV-infected women had normal cytology. The overall prevalence of LSIL and HSIL associated to HPV in the studied groups was $24.3 \%$ (I7/70) and $31.4 \%$ (22/70) respectively. Among the 22 HSIL-positive women, $63.6 \%$ (14/22) were not on antiretroviral therapy, while $36.4 \%$ (8/22) were under HAART. HIV infected women under HAART with positive HSIL, showed a median CD4+ T cell count of $253.7+/-31.7$ higher than those without therapy $(164.7+/-26.1)$. The incidence of HSIL related to HPV infection within the study group independently of HAART initiation was high.

Conclusion: These results suggest the need for extension and expansion of the current study in order to evaluate the incidence of HPV infection and cervical cancer among HIV-infected and non HIV- infected women in Cameroon. 


\section{Background}

Genital infection by human papillomavirus (HPV) is one of the most common sexually transmitted infections, known to be the cause of cervical cancer [1-3]. Although HPV is known to be strongly associated with the development of cervical cancer, most HPV infections in young women are transient [4]. Women with persistent infection appear to have a higher risk of developing significant cervical cancer $[2,5]$. The burden of this infection on public health is compounded by the recognized causal relations between genital HPV infection and cervical dysplasia or cervical cancer $[6,7]$. Although factors that influence persistence of HPV are not yet well understood, several studies suggest that alterations in cell mediated immune responses play a major role in persistence of HPV. The higher rates of HPV infection, high-grade squamous intraepithelial lesion (HSIL), and cervical cancer among immunosuppressed individuals, specifically HIV-infected women, underscore the importance of control of immune response in HPV infection. Studies on adult women have consistently shown that the prevalence of HPV infection and HSIL are higher among HIV infected women and that these differences are exaggerated among women with lower CD4+ cell counts [8-10]. Several recent prospective studies have documented that the rate of persistence of HPV among HIV-infected women is higher than that among non HIV-infected women $[11,12]$. Specific types of HPV are associated with cervical cancer, but whether these high-risk types have natural histories that are different from those of other types not associated with cervical cancer is unknown $[13,14]$. The modification of the viral markers may be the crucial factor of disequilibrium in the interaction between virus and host: an increased replicating capacity of the virus versus a reduced control mechanism of the immune system. In this context it's evident that in HIV-infected women, both viral and host factors conspire, as these patients have an impaired immune system usually more exposed to HPV infection. Some studies have also considered the impact on cervical pathology on HIV disease care, mainly represented by the introduction of highly active antiretroviral therapy (HAART), which through the substantial recovery of immune function has significantly changed the scenario regarding HIV-related pathologies such as opportunistic infections and cancers $[15,16]$. The objectives of this study were to compare rates of cervical abnormalities related to HPV infection among HIV-infected women with and without HAART initiation and to examine immunological and behavioural risk factors associated with persistence of HPV.

\section{Subjects and methods Study population}

A total of $70 \mathrm{HIV}$-infected women were enrolled in the study after informed consent and divided into two groups: 35 under HAART and 35 not initiated with HAART.
Within eight (08) month, patients aged between 21-56 years, were recruited in a day care centre at Bonassama hospital in Douala for HIV therapy. All were included in a pilot study on clinical and behavioural characteristics associated with HIV infection. The study was carried out according to the guidelines for human experimental models in clinical research as stated by the ministry of public Health of Cameroon.

\section{Inclusion criteria}

Enrolled women were single or married; non-pregnant; aged 21 years old and above and HIV infected, initiated or not with HAART. Patients were divided in two groups: group one consisted of women who were diagnosed HIV positive and were not yet eligible for antiretroviral therapy. Patients in this group were considered untreated only at the beginning of the study. The second group comprised HIV-infected women receiving HAART, who were enrolled on the basis of a three months' minimum length of treatment. Patients in this group had different therapeutic protocols spread over different periods of treatment. From the list of patients eligible for the study, subjects were randomly chosen in a systematic manner. The objective of the study was explained to patients and verbal consent was sought from each of them.

\section{Collection of Specimens}

At the screening visit, venous blood was collected for CD4 analysis, and pap smears performed for early detection of cervical carcinoma as previously described [17]. Subjects underwent a general physical examination and completed a short standardized interview, including questions pertaining to medical history, sexual behaviour, history of STIs, age of first sexual intercourse, pregnancy, parity and abortion.

\section{Histological analysis}

Pap smears were interpreted and classified according to the Bethesda System as negative, atypical squamous cells of unknown significance, LSIL, HSIL, or invasive cervical cancer $[18,19]$. Conventional Pap smears were used and slides were read by a pathologist. Blood samples were obtained for flow cytometry CD4+ T cell counts using AIDS Clinical Trials Group standardized flow-cytometry protocols as described elsewhere [20].

\section{Statistical analysis}

Data obtained were verified for consistency, coded, and computerized. Throughout the text, values are given as mean \pm s.d. Percentages were calculated from the overall number of cases. Raw data were compared using Fisher's exact-test (StatXact 2.05 software). Appropriate probabilities were calculated [21] and size variation with MannWhitney rank sum test as the normality test failed (Sigma Stat 2.03 software). 


\section{Results}

\section{Subjects characteristics}

Seventy HIV infected women were randomly recruited using systemic random sampling from the outpatients at the day care centre of Bonassama hospital in Douala. Table 1 summarizes the socio-demographic information as well as information on reproductive and sexual characteristics of the study groups. Sampling was done according to: age with a mean age of $35.5 \pm 1.9$ years and $35.1 \pm 1.3$ years; age of first vaginal sex with a mean age of $16.9 \pm 5$ years and $17.2 \pm 0.5$ years; number of pregnancies with a mean number of $3.7 \pm 0.5$ and $3.9 \pm 0.4$; parity with a mean number of $2.6 \pm 0.5$ and $2.6 \pm 0.4$; abortion with a mean number of $1.2 \pm 0.2$ respectively for women under HAART and women not initiated with HAART. Significant differences were observed between these groups at baseline in terms of ages of patients: when comparing the mean age of patients above 40 years $(52.3 \pm 2.3 \%$ (9) vs. $44.9 \pm 1.2 \%(10), \mathrm{P}=0.007)$ and when comparing the mean parity of more than $4(9.8 \pm 0.7 \%$ (4) vs. $5.9 \pm 0.5 \%$ $(8), P=0.006)$ for treated and untreated group respectively. The significant difference observed between treated and untreated groups in terms of mean age and parity is probably due to the number patients assigned to each parameter.

\section{HAART and incidence of cervical abnormalities}

Table 2 presents histological analyses of studied samples. The Pap smear test results revealed the following within the study groups: those with normal cervical cytology $(44.3 \%)$ and those with abnormal Pap smear; LSIL (24.3\%), and HSIL (31.4\%) respectively. The cervical abnormalities differences were statistically significant for the two study groups when comparing the total frequency abnormalities $(48.6 \%$ vs. $62.9 \%, \mathrm{P}=0.034)$ for treated and untreated groups respectively. Table 3 represents the frequency of distribution of cervical cytology results in the treated and untreated groups according to the duration of therapy. Cervical abnormalities are high in the absence of therapy: $47.1 \%$ and $63.6 \%$ for LSIL and HSIL respectively. The difference in the distribution of the cytological picture among LSIL and HSIL cases was statistically none significant $(P>0.05)$. Table 4 represents the Incidence of cervical cytology results in the HAART treatment group according to the duration of therapy. Normal cervical cytology increase with the duration of therapy: $5.7 \%$ to $34.3 \%$ within the period of treatment $1-5$ month and

Table I: Selected baseline characteristics of HIV infected women as study subjects.

\begin{tabular}{|c|c|c|c|c|c|c|c|}
\hline \multirow[b]{2}{*}{ Groups } & \multicolumn{3}{|c|}{ Under HAART } & \multicolumn{3}{|c|}{ No HAART } & \multirow[b]{2}{*}{$P$ value } \\
\hline & $\mathrm{n}$ & $\%$ & Mean $\pm S E^{a}$ & $\mathrm{n}$ & $\%$ & Mean \pm SE & \\
\hline \multicolumn{8}{|c|}{ A. Age (years) } \\
\hline$<30$ & 12 & 34.3 & $26.4 \pm 0.7$ & 10 & 28.6 & $26.4 \pm 0.9$ & $0.988 \mathrm{~ns}$ \\
\hline $30-40$ & 14 & 40.0 & $32.4 \pm 0.8$ & 15 & 42.8 & $34.3 \pm 0.9$ & $0.115 \mathrm{~ns}$ \\
\hline$>40$ & 9 & 25.7 & $52.3 \pm 2.3$ & 10 & 28.6 & $44.9 \pm 1.2$ & $0.007 *$ \\
\hline Total & 35 & - & $35.5 \pm 1.9$ & 35 & - & $35.1 \pm 1.3$ & $0.872 \mathrm{~ns}$ \\
\hline \multicolumn{8}{|c|}{ B. Age at first vaginal sex (years) } \\
\hline$\leq 16$ & 18 & 51.4 & $14.6 \pm 0.3$ & 15 & 42.9 & $14.5 \pm 0.3$ & $0.874 \mathrm{~ns}$ \\
\hline$>16$ & 17 & 48.6 & $19.3 \pm 0.7$ & 20 & 57.1 & $19.3 \pm 0.4$ & $0.956 \mathrm{~ns}$ \\
\hline Total & 35 & - & $16.9 \pm 0.5$ & 35 & - & $17.2 \pm 0.5$ & $0.643 \mathrm{~ns}$ \\
\hline \multicolumn{8}{|c|}{ C. Pregnancy } \\
\hline 0 & 2 & 5.7 & $0.0 \pm 0.0$ & 0 & 0.0 & $0.0 \pm 0.0$ & - \\
\hline I-4 & 23 & 65.7 & $2.3 \pm 0.3$ & 22 & 62.9 & $2.3 \pm 0.2$ & $0.971 \mathrm{~ns}$ \\
\hline $5-9$ & 7 & 20.0 & $6.1 \pm 0.6$ & 11 & 31.4 & $5.9 \pm 0.4$ & $0.750 \mathrm{~ns}$ \\
\hline$>10$ & 3 & 8.6 & $11.0 \pm 0.6$ & 2 & 5.71 & $10.5 \pm 0.5$ & $0.800 \mathrm{~ns} \#$ \\
\hline Total & 35 & - & $3.7 \pm 0.5$ & 35 & - & $3.9 \pm 0.4$ & $0.737 \mathrm{~ns}$ \\
\hline \multicolumn{8}{|l|}{ D. Parity } \\
\hline 0 & 7 & 20.0 & $0.0 \pm 0.0$ & 5 & 14.3 & $0.0 \pm 0.0$ & - \\
\hline $1-4$ & 24 & 68.6 & $2.1 \pm 0.3$ & 22 & 62.8 & $2.0 \pm 0.2$ & $0.71 \mathrm{Ins}$ \\
\hline$>4$ & 4 & 11.4 & $9.8 \pm 0.7$ & 8 & 22.8 & $5.9 \pm 0.5$ & $0.006 *$ \\
\hline Total & 35 & - & $2.6 \pm 0.5$ & 35 & - & $2.6 \pm 0.4$ & $0.964 \mathrm{~ns}$ \\
\hline \multicolumn{8}{|c|}{ E. Abortion } \\
\hline 0 & 13 & 37.1 & $0.0 \pm 0.0$ & 12 & 34.3 & $0.0 \pm 0.0$ & - \\
\hline $1-2$ & 15 & 42.9 & $1.2 \pm 0.1$ & 17 & 48.6 & $1.4 \pm 0.1$ & $0.353 \mathrm{~ns}$ \\
\hline$>2$ & 7 & 20.0 & $3.4 \pm 0.2$ & 6 & 17.1 & $3.3 \pm 0.3$ & $0.628 \mathrm{~ns}$ \\
\hline Total & 35 & - & $1.2 \pm 0.2$ & 35 & - & $1.2 \pm 0.2$ & $0.925 \mathrm{~ns}$ \\
\hline
\end{tabular}

a. Means were compared one after the other using the Student t-test when normality and equal variance conditions passed or the Mann-Whitney rank sum test when conditions failed.

Ns: no significant difference; * significant difference; \#: Mann-Whitney rank sum test 
Table 2: Frequency of cervical abnormalities in HIV infected women according to cytological findings

\begin{tabular}{|c|c|c|c|c|c|c|c|}
\hline \multirow[b]{2}{*}{ Groups } & \multicolumn{2}{|c|}{ Under HAART(35) } & \multicolumn{2}{|c|}{ No HAART (35) } & \multicolumn{2}{|c|}{ Total (70) } & \multirow[t]{2}{*}{ p-value } \\
\hline & $\mathrm{n}$ & $\%$ & $\mathrm{n}$ & $\%$ & $\mathrm{n}$ & $\%$ & \\
\hline Normal & 18 & 51.4 & 13 & 37.1 & 31 & 44.3 & \\
\hline LSILa & 9 & 25.7 & 8 & 22.9 & 17 & 24.3 & \\
\hline HSILb & 8 & 22.9 & 14 & 40.0 & 22 & 31.4 & \\
\hline Total abnormalities & 17 & 48.6 & 22 & 62.9 & 39 & 55.7 & $0.034^{*}$ \\
\hline
\end{tabular}

a. Low squamous intra epithelial lesions b. High squamous intra epithelial lesions

* Significant difference

more than 10 month respectively. Within the same period, HSIL decreased from $14.3 \%$ to $2.8 \%$ and was probably due to the number of patients within the more than 10 months' period of therapy. The difference in the incidence of cervical abnormalities was statistically non significant $(\mathrm{P}=0.069)$. Table 5 represents $\mathrm{CD} 4+\mathrm{T}$ cell count distribution within the study groups according to cervical abnormalities. The mean of $\mathrm{CD} 4+\mathrm{T}$ cell count decreases with degree of cervical abnormalities in both groups: $289 \pm 47.0,253 \pm 69.1$ and $173.4 \pm 42.4$ T cells in patients under HAART while those with no HAART initiation have $244.5 \pm 42.8,218.4 \pm 64.1$ and $59.9 \pm 14.5$ for normal, LSIL and HSIL respectively. Table 6 examines some of the risk factors that might contribute to HPV infection. The risk factors investigated were grouped according to the following parameters of personal history: age of first vaginal sex, pregnancy and abortion. The results showed that patients with cervical abnormalities were mainly $\geq 19$ years old at first vaginal sex intercourse with high percentage: $23.5 \%$ and $20.2 \%$ for LSIL and HSIL respectively. There was no statistical difference for this factor when compared with Mann-Whitney test. Reproductive history of the studied groups showed a statistically non significant difference between the LSIL and HSIL pos-

Table 3: Frequency of cervical abnormalities in HIV infected women according to duration of medication (HAART)

\begin{tabular}{|c|c|c|c|c|c|}
\hline \multirow{3}{*}{$\begin{array}{l}\text { Duration } \\
\text { (month) }\end{array}$} & \multicolumn{4}{|c|}{ Cervical abnormalitya } & \multirow[b]{3}{*}{ Exact $p$-value ${ }^{b}$} \\
\hline & \multicolumn{2}{|c|}{ LSIL } & \multicolumn{2}{|c|}{ HSIL } & \\
\hline & $\mathrm{n}$ & $\%$ & $\mathrm{n}$ & $\%$ & \\
\hline 0 & 08 & 47.1 & 14 & 63.6 & $0.1308 \mathrm{~ns}$ \\
\hline $\mathrm{I}-5$ & 03 & 17.7 & 05 & 22.7 & $0.6193 \mathrm{~ns}$ \\
\hline $6-10$ & 02 & 11.8 & 02 & 09.1 & $1.000 \mathrm{~ns}$ \\
\hline$>10$ & 04 & 23.5 & 01 & 04.5 & $0.2063 \mathrm{~ns}$ \\
\hline Total & 17 & - & 22 & - & $0.3652 \mathrm{~ns}$ \\
\hline
\end{tabular}

a. Combined data for treated and untreated patients

b. Global comparison of raw data: Pearson's chi-square exact probability: $P=0.3725$ ) itive patients neither for pregnancy nor for abortion. In patients with the highest percentage for pregnancies, i.e. $\leq$ 10 pregnancies we noticed $76.4 \%$ and $45.5 \%$ occurrence for LSIL and HSIL respectively while for abortion, the cytology results findings showed $70.6 \%$ and $36.4 \%$ for LSIL and HSIL respectively in patients with 1 or more than 2 abortions. Table 7 represents distribution of STI risk factors that might contribute to HPV infection. The history of STIs risk factors shows that: Bacillus vaginalis, Chlamydia sp and Treponema Pallidum are main microbial infectious agents. B. vaginalis is the leading infection with $70.6 \%$ and $54.5 \%$ for LSIL and HSIL respectively while Chlamydia is the second with $17.6 \%$ and $22.7 \%$ and T. Pallidum which count for $5.9 \%$ and $13.6 \%$ respectively for LSIL and HSIL positives patients. No significant statistical difference was found in correlation with cervical abnormalities.

\section{Discussion}

This study provides data on the risk of cervical cancer among HIV positive women less than 60 years old in the day care centre at Bonassama hospital Douala -Central Africa. The extent to which HIV increases the risk for cervical cancer is especially important in Cameroon referring to the epidemiology of the HIV especially among women. In our study, HIV positive women are at high risk of invasive cervical cancer. This could be due to the competing risk of mortality from other conditions associated with

Table 4: Cervical abnormalities incidence in HIV infected women under HAART therapy according to and duration of medication

\begin{tabular}{|c|c|c|c|c|c|c|}
\hline \multirow{2}{*}{$\begin{array}{l}\text { Duration } \\
\text { (month) }\end{array}$} & \multicolumn{2}{|c|}{ Normal } & \multicolumn{2}{|c|}{ LSIL } & \multicolumn{2}{|c|}{ HSIL } \\
\hline & $\mathrm{n}$ & $\%$ & $\mathrm{n}$ & $\%$ & $\mathrm{n}$ & $\%$ \\
\hline 0 & - & - & - & - & - & - \\
\hline $1-5$ & 2 & 5.7 & 3 & 8.6 & 5 & 14.3 \\
\hline $6-10$ & 4 & 11.4 & 2 & 5.7 & 2 & 5.7 \\
\hline$>10$ & 12 & 34.3 & 4 & 11.4 & 1 & 2.8 \\
\hline Total & 18 & 51.4 & 9 & 25.7 & 8 & 22.8 \\
\hline
\end{tabular}

a. exact probability using Pearson's Chi-square test for independence procedure: $P=0.069$ 
Table 5: CD4+ T cell count distribution in HIV infected women according to cervical abnormalities

\begin{tabular}{|c|c|c|c|c|c|c|}
\hline \multirow[b]{2}{*}{ Groups } & \multicolumn{3}{|c|}{ Under HAART } & \multicolumn{3}{|c|}{ No HAART } \\
\hline & $\mathrm{n}$ & $\%$ & Mean \pm SE & $\mathrm{n}$ & $\%$ & Mean \pm SE \\
\hline Normal & 18 & 51.4 & $289.4 \pm 47.0$ & 13 & 37.1 & $244.5 \pm 42.8$ \\
\hline LSIL & 9 & 25.7 & $253.6 \pm 69.1$ & 8 & 22.9 & $218.4 \pm 64.1$ \\
\hline HSIL & 8 & 22.9 & $173.4 \pm 42.4$ & 14 & 40.0 & $59.9 \pm 14.5$ \\
\hline Total & 35 & - & $253.7 \pm 31.7$ & 35 & - & $164.7 \pm 26.1$ \\
\hline
\end{tabular}

HIV/AIDS, particularly in a setting where antiretroviral therapy was not available at the time and for all patients. Our findings that HIV infected women were at a significantly higher risk of LSIL and HSIL confirm the results of studies carried out in both developed and other developing countries $[7,17,22-24]$. The relative prevalence of SILs or cytological abnormalities among HIV positive women is higher than that ever been reported by any other study in Africa. Hawes et al. reported a cytological abnormality prevalence of $37 \%$ among women with HIV-1 infection attending an outpatients infectious disease clinic in Senegal [17], Yamada 27.1\% in urban patients in Kenya [25], Moukassa 15.36\% among urban dwellers in Congo [26].

A potential limitation of this current study is that cytological abnormalities were not histologically confirmed. However, it has been shown that the Pap smear sensitivity and specificity are similar among HIV negative and HIV positive women [27]. We found an association between HAART and the stage of cervical pre-cancer. Our results are in agreement with others that have shown an association between HIV, HAART and cervical abnormalities [[15,16], and [28]]. An additional limitation of our study is that complete information regarding the immunological status of patients has not been documented for all the groups. Similar of different studies by the same author $[[9,15,16,20,25]$, and [29]] have reported that the severity of HIV-related immunodepression is associated with increased incidence of HPV infection and SILs. Data obtained from the current study further confirm these findings reported by other investigators of our geographic area $[17,22-26]$. Several studies suggested that markers of advanced HIV disease such as CD4+ T cell counts or HIVRNA plasmatic levels are associated with increased risk of HPV infection and SIL $[8,17,28,29]$. However some documentations and data have revealed that the relationship between HIV and HPV is more complex. Human immunodeficiency virus infection is associated with an increased transcriptional activity of early HPV genes. Studies on adult women have shown that HPV infection with both high-risk and low-risk HPV types is more likely to persist among HIV-infected women $[8,12]$. Because they have more years of sexual activity, adult women may reflect a group of women further along in their history of HIV and HPV infection. Our data further support the important role played by CD4+ T cells $[28,29]$ in the control of HPV

Table 6: Incidence of risk factors on cervical disease in HIV infected women under treatment (HAART) and those without treatment or HAART initiation

\begin{tabular}{|c|c|c|c|c|c|c|c|}
\hline \multirow[b]{2}{*}{ Groups } & \multicolumn{3}{|c|}{ LSIL } & \multicolumn{3}{|c|}{ HSIL } & \multirow[t]{2}{*}{ Mann-Withney test } \\
\hline & $\mathrm{n}$ & $\%$ & Mean \pm SE & $\mathrm{n}$ & $\%$ & Mean \pm SE & \\
\hline \multicolumn{8}{|c|}{ Age at first vaginal sex (years) } \\
\hline$<15$ & 03 & 17.6 & $13.7 \pm 0.3$ & 06 & 27.3 & $13.2 \pm 0.3$ & $0.381 \mathrm{~ns}$ \\
\hline $15-18$ & 10 & 58.8 & $16.5 \pm 0.5$ & 11 & 50.0 & $16.4 \pm 0.3$ & $0.860 \mathrm{~ns}$ \\
\hline$\geq 19$ & 04 & 23.5 & $19.8 \pm 0.5$ & 05 & 22.7 & $20.2 \pm 0.7$ & $0.905 \mathrm{~ns}$ \\
\hline Total & 17 & - & $16.8 \pm 0.5$ & 22 & - & $16.4 \pm 0.6$ & $0.57 \mathrm{Ins}$ \\
\hline \multicolumn{8}{|c|}{ Pregnancy } \\
\hline$\leq 4$ & 13 & 76.4 & $2.4 \pm 0.3$ & 10 & 45.5 & $2.8 \pm 0.3$ & $0.420 \mathrm{~ns}$ \\
\hline $5-9$ & 02 & 11.8 & $5.5 \pm 0.5$ & 10 & 45.5 & $1.4 \pm 0.4$ & $0.590 \mathrm{~ns}$ \\
\hline$\geq 10$ & 02 & 11.8 & $11.5 \pm 0.5$ & 02 & 09.0 & $0.7 \pm 0.5$ & $0.333 \mathrm{~ns}$ \\
\hline Total & 17 & - & $3.8 \pm 0.8$ & 22 & - & $5.1 \pm 0.6$ & $0.068 \mathrm{~ns}$ \\
\hline \multicolumn{8}{|c|}{ Abortion } \\
\hline 0 & 03 & 17.6 & $0.0 \pm 0.0$ & 06 & 27.3 & $0.0 \pm 0.0$ & - \\
\hline $1-2$ & 12 & 70.6 & $1.3 \pm 0.3$ & 08 & 36.4 & $1.4 \pm 0.2$ & $0.669 \mathrm{~ns}$ \\
\hline$>2$ & 02 & 11.7 & $3.0 \pm 0.0$ & 08 & 36.4 & $3.6 \pm 0.3$ & $0.400 \mathrm{~ns}$ \\
\hline Total & 17 & - & $1.24 \pm 0.2$ & 22 & - & $1.8 \pm 0.3$ & $0.372 \mathrm{~ns}$ \\
\hline
\end{tabular}


Table 7: Incidence of History of STD on cervical disease in HIV infected untreated and treated women (exact probability using Pearson's Chi-square test for independence procedure: $\mathbf{P}=$ 0.8224)

\begin{tabular}{lccccc}
\hline & \multicolumn{2}{c}{ LSIL } & & \multicolumn{2}{c}{ HSIL } \\
\cline { 2 - 3 } \cline { 5 - 6 } Groups & $\mathrm{n}$ & $\%$ & & $\mathrm{n}$ & $\%$ \\
\hline B. vaginalis & 12 & 70.6 & & 12 & 54.5 \\
Chlamydia & 03 & 17.6 & & 05 & 22.7 \\
T. Pallidum & 01 & 05.9 & & 03 & 13.6 \\
Other & 01 & 05.9 & & 02 & 09.1 \\
\hline Total & 17 & - & & 22 & - \\
\hline
\end{tabular}

infection: the lower the CD4+ T cell count, the more likely that HPV infection will persist. Persistent infection in turn may increase the risk for the development and persistence of squamous intraepithelial lesions. In fact, women whose immunosuppression is related to infection with human immunodeficiency virus are at increased risk of infection with multiple types of HPV [28]. In developed countries it's recommended for HIV positive women to have two cervical cytological assessments within the first year after HIV diagnosis and annually thereafter, referred for colposcopy for any smear showing an ASCUS (atypical squamous cells of undetermined significance) or more severe lesions [30]. These guidelines are not feasible in settings with limited or poor resources. The high prevalence and risk of cervical abnormalities documented in our research projet underscores the importance of developing screening and management guidelines for HIV positive women. As antiretroviral therapy becomes increasingly available in Cameroon, the life expectancy of HIV positive women will increase as well. It's therefore important to conserve this invaluable benefit and avoid its upset by an increased risk in the development of cervical cancer. A cervical screening program is of critical importance as it informs local researchers on the natural history of cervical abnormalities, which might be recommended for HIV positive women. The STIs history of studied subjects revealed the presence of reproductive tract infection in patients with cervical cytology abnormality. This high rate of infection is attributed to the promiscuous sexual behaviour of the sampled women. Other studies suggest lack of hygiene, crowded or unsanitary living conditions, stress, and the presence of other sexually transmitted infections as factors that spread HPV infection and, eventually cervical cancer [30]. In the current study, history of STI infections was a non significant risk predictor in distinguishing LSIL to HSIL positive cases.

\section{Conclusion}

HPV infection increased in accordance with lower CD4+ T cell counts and higher HIV RNA levels. High-grade lesions were strongly associated with high-risk HPV infection and low CD4+ T cell counts. Immunodeficiency as a result of HIV infection appears to be important for malignant progression within the cervix. Nationwide prevention of HIV infection and cervical cancer screening are necessary for the health of women in Cameroon. The increased public health burden enhanced by HPV is an important and gender-specific aspect of HIV infection. Guidelines on proper screening for cervical abnormalities in HIV positive women are urgently needed in Cameroon.

\section{Competing interests}

The authors declare that they have no competing interests.

\section{Authors' contributions}

KMML conceived the study, participated in its design and statistical analysis, coordinated and drafted the manuscript. GMLC participated in CD4 analysis using the flow cytometry, data collection and helped to draft the manuscript. DC participated in flow cytometry analysis, data collection and helped to draft the manuscript. WM participated in study design, clinical examination and recruitment of women at the study site and coordination. MA carried out cytology analysis. NNA participated in the study design, statistical analysis and helped to draft and review the manuscript.

\section{Acknowledgements}

These results were obtained thanks to the support of AIRES-Sud, a programme from the French Ministry of Foreign and European Affairs implemented by the Institut de Recherche pour le Développement (IRD-DSF). The authors thank the women for their voluntary participation in the study. We would equally like to give thanks to Dr Lehman Leopold for his technical assistance via the flow cytometry, Dr Kenne Martin for statistics analysis assistance and Mr Ewane Leonard for manuscript review.

\section{References}

I. Bosch FX, Munoz N: The viral etiology of cervical cancer. Virus Res 2002, 89:183-189.

2. Walboomers JM, Jacobs MV, Manos MM, Bosch FX, Kummer JA, Shah KV, Snijders PJ, Peto J, Meijer CJ, Munoz N: Human papillomavirus is a necessary cause of invasive cervical cancer worldwide. J Pathol 1999, 189:12-19.

3. Schiffman $\mathrm{MH}$ : New epidemiology of human papillomavirus infection and cervical neoplasia. I Natl Cancer Inst 1995, 87: 1345-1347.

4. Ho GY, Bierman R, Beardsley L, Chang CJ, Burk RD: Natural history of cervicovaginal papillomavirus infection in young women. N Engl J Med 1998, 338:423-428.

5. Strickler HD, Burk RD, Fazzari M, Anastos K, Minkoff H, Massad LS, Hall C, Bacon M, Levine AM, Watts DH, Silverberg MJ, Xiaonan Xue, Schlecht NF, Melnick S, Palefsky JM: Natural History and Possible Reactivation of Human Papillomavirus in Human Immunodeficiency Virus - Positive Women. J Nat Can Inst 2005, 97(8):577-586.

6. Pisani P, Parkin M, Muñoz N, Ferlay J: Cancer and infection: estimates of the attributable fraction in 1990 . Cancer Epidemiol Biomarkers Prev 1997, 6:387-400.

7. Parkin DM, Bray F, Ferlay J, Pisani P: Global cancer statistics 2002. Cancer J Clin 2005, 55:74-I08.

8. Heard I, Tassie JM, Schmitz V, Mandelbrot L, Kazatchkine MD, Orth $\mathrm{G}$ : Increased risk of cervical disease among human immunodeficiency virus-infected women with severe immunosup- 
pression and high human papillomavirus load(I). Obstet Gynecol 2000, 96:403-409.

9. Ellerbrock TV, Chiasson MA, Bush TJ, Sun XW, Sawo D, Brudney K, Wright TC: Incidence of Cervical Squamous Intraepithelial Lesions in HIV-Infected Women. JAMA 2000, 283:I03I-I037.

10. Ho GYF, Bierman R, Beardsley L, Chang CJ, Burk RD: Natural history of cervicovaginal papillomavirus infection in young women. N Engl J Med 1998, 338:423-428.

II. Ahdieh L, Klein RS, Burk R, Cu-Uvin S, Schuman P, Duerr A, Safaeian $M$, Astemborski J, Daniel R, Shah K: Prevalence, incidence, and type-specific persistence of human papillomavirus in human immunodeficiency virus (HIV) positive and HIV-negative women. J Infect Dis 200I, 184:682-690.

12. Cubie HA, Seagar AL, Beattie GJ, Monaghan S, Williams AR: A longitudinal study of HPV detection and cervical pathology in HIV-infected women. Sex Transm Infect 2000, 76:257-26I.

13. Bosch FX, Manos MM, Munoz N, Sherman M, Jansen AM, Peto J, Schiffman MH, Moreno V, Kurman R, Shah KV: Prevalence of human papillomavirus in cervical cancer: a worldwide perspective: International Biological Study on Cervical Cancer (IBSCC) Study Group. J Natl Cancer Inst 1995, 87:796-802.

14. Strickler HD, Palefsky JM, Shah KV, Anastos K, Klein RS, Minkoff H, Duerr A, Massad LS, Celentano DD, Hall C, Fazzari M, Cu-Uvin S, Bacon M, Schuman P, Levine AM, Durante AJ, Gange S, Melnick S, Burk RD: Human Papillomavirus Type 16 and Immune Status in Human Immunodeficiency Virus-Seropositive Women. J Natl Cancer Inst 2003, 95: 1062-I07I.

15. Uberti-Foppa C, Ferrari D, Lodini S, Reina S, Ameglio F, Grasso MA, Gallotta G, Ferrari A, Taccagni G, Lazzarin A, Lillo FB: Long-term effect of highly active antiretroviral therapy on cervical lesions in HIV-positive women. AIDS 2003, 17:2136-2138.

16. Lillo FB, Ferrari D, Veglia F, Origoni M, Grasso MA, Lodini S, Mastrorilli E, Taccagni G, Lazzarin A, Uberti-Foppa C: Human papillomavirus infection and associated cervical disease in human immunodeficiency virus infected women: effect of highly active antiretroviral therapy. J Infect Dis 200I, 184:547-55I.

17. Hawes SE, Critchlow CW, Faye Niang MA, Diouf MB, Diop A, Toure P, Aziz Kasse A, Dembele B, Salif Sow P, Coll-Seck AM, Kuypers JM, Kiviat NB: Increased risk of high-grade cervical squamous intraepithelial lesions and invasive cervical cancer among African women with human immunodeficiency virus type I and 2 infections. J Infect Dis 2003, I 88:555-563.

18. Nieminen P, Vuorma S, Viikki M, Hakama M, Antila A: Comparison of HPV test versus conventional and automation-asisted Pap screening as potential screening tools for preventing cervical cancer. BJOG 2004, I I I:842-848.

19. Solomon D, Davey D, Kurman R, Moriarty A, O'Connor D, Prey M, Raab S, Sherman M, Wilbur D, Wright TJ, Young N, for the Forum Group Members and the Bethesda 2001: The 200I Bethesda System: Terminology for Reporting Results of Cervical Cytology. JAMA 2002, 287:21।4-2।I9.

20. Nicol AF, Fernandes ATG, Grinsztejn B, Russomano F, Lapa e Silva JR, Tristão A, Pérez M, Nuovo G], Martínez-Maza O, Bonecini-Almeida MG: Distribution of immune cell and cytokine producing cells in the uterine cervix of human papillomavirus infected women: influence of HIV-I coinfection. Diag Mol Pathol 2004, I 4(1):39-47.

21. Thompson WD: Statistical analysis of case-control studies. Epidemiol Rev 1994, 16:33-50.

22. Jennifer RM, Margaret $H$, Henri C, Bruce RA, Diane DC, Lynn R, Lynette ED, Samuel S, Anna-Lise W: HIV and pre-neoplastic and neoplastic lesions of the cervix in South Africa: a case-control study. BMC Cancer 2006, 6: I35-14I.

23. Blossom DB, Beigi RH, Farrell J], Mackay W, Qadadri B, Brown DR, Rwambuya S, Walker CJ, Kambugu FS, Abdul-Karim FW, Whalen CC, Salata RA: Human papillomavirus genotypes associated with cervical cytologic abnormalities and HIV infection in Ugandan women. J Med Virol 2007, 79(6):758-765.

24. López-Revilla R, Martínez-Contreras LA, Sánchez-Garza M: Prevalence of high-risk human papillomavirus types in Mexican women with cervical intraepithelial neoplasia and invasive carcinoma. Infectious Agents and Cancer 2008, 3:3-10.

25. Yamada R, Sasagawa T, Kirumbi LW, Kingoro A, Karanja DK, Kiptoo $M$, Nakitare GW, Ichimura $H$, Inoue $M$ : Human papillomavirus infection and cervical abnormalities in Nairobi, Kenya, an area with a high prevalence of human immunodeficiency virus infection. J Med Virol. 2008, 80(5):847-855.

26. Moukassa D, N'Golet A, Lingouala LG, Eouani ML, Samba JB, Mambou JV, Ompaligoli S, Moukengue LF, Taty-Pambou E: Precancerous lesions of the uterine cervix in Pointe-Noire, Congo. Med Trop (Mars). 2007, 67(I):57-60.

27. Branca M, Rossi E, Alderisio M, Migliore G, Morosini PL, Vecchione A, Sopracordevole F, Mudu P, Leoncini L, Syrjanen K: Performance of cytology and colposcopy in diagnosis of cervical intraepithelial neoplasia (CIN) in HIV-positive and HIV-negative women. Cytopathology 200I, I 2:84-93.

28. Alcina FN, Ana TGF, Maria da GB: Immune response in cervical dysplasia induced by humanpapillomavirus: the influence of human immunodeficiency virus-I co-infection - Review. Mem Inst Oswaldo Cruz, Rio de Janeiro 2005, I 00(I): I-I2.

29. De Jong A, van Poelgeest MIE, Hulst JM van der, Drijfhout JW, Fleuren G], Melief CJM, Kenter G, Offringa R, Burg SH van der: Human Papillomavirus Type 16-Positive Cervical Cancer Is Associated with Impaired CD4+ T-Cell Immunity against Early Antigens E2 and E6. Cancer Res 2004, 64:5449-5455.

30. Centres for Disease Control: I 997 USPHS/IDSA Guidelines for the prevention of opportunistic infections in persons infected with human immunodeficiency virus. MMWR I997, 46: $1-26$
Publish with Biomed Central and every scientist can read your work free of charge

"BioMed Central will be the most significant development for disseminating the results of biomedical research in our lifetime. "

Sir Paul Nurse, Cancer Research UK

Your research papers will be:

- available free of charge to the entire biomedical community

- peer reviewed and published immediately upon acceptance

- cited in PubMed and archived on PubMed Central

- yours - you keep the copyright 